\title{
Metallurgy in the Early Steppes
}

\section{KARL JETTMAR}

The results obtained from analyses of copper and bronze implements for the origin and diffusion of metalwork in some parts of the Old World in the fourth to second millennium в.c. will be briefly summarized here. ${ }^{1}$

In Europe copper appeared in the middle of the third millennium в.c. in the framework of a developed technology in two marginal regions, in Spain and Portugal and on the shores of the Aegean. From both centers ready-made implements were exported over large areas mostly by sea trade.

Somewhat later, copper deposits in many parts of Europe began to be used and imported copper disappeared. During this lengthy process the casting of copper in complex molds had been replaced by casting in open molds and subsequent hammering. Only with the advent of an alloy of high quality, copper and tin-which we commonly call bronze-was there a return to the earlier casting techniques.

Scholars in the Soviet Union using spectrographic analyses for metal objects deriving from areas larger than those of Europe, generally aim to determine the metallurgical district in which the ore originated rather than attempt to find the specific deposit from which the ore of a given group of objects could have come.

The earliest implements made of copper in the Soviet Union are attested in Turkmenia. In the early fourth millennium B.c. copper ores were used which had a high lead content. Later they were replaced by others which have arsenic and antimony as natural admixtures. Here too the items were cast in open molds and subsequently hammered cold to increase hardness and toughness.

The metallurgy of Turkmenia was certainly derived from Iran, even the copper may have been imported from the Elburz mountains or from some other area in Northeast Iran although metal analyses from these regions are not yet available.

Moldavia and the western half of the Ukraine were also exposed to the impact of foreign metal-

1 The paper of which the first part is here summarized will be printed in unabridged form with illustrations in Artibus Asiae.

2 Apparently arsenic bronzes produce as good an alloy as tin bronzes, if not better, but the dangers involved in working with lurgy. In the first half of the third millennium B.c. the people of the Tripolye culture used copper from the Balkans mostly in the form of ornaments.

The composition and sources of the copper and bronze used in the various areas of the Soviet Union reflect patterns of foreign relations. Thus the Fatianovo culture of Central Russia, which continued to use unalloyed copper in the second millennium B.c., was probably related to cultures of Central European type in which copper was generally replaced by bronze only about 1700 B.c.

Proceeding southward, the next area for consideration of copper and bronze is Azerbaijan, south of the Caucasus range, where implements of relatively pure copper were found in contexts of the fourth millennium в.c. In the third millennium bronzes containing not tin but a high percentage of arsenic were found in a much larger area which included both Transcaucasia and Ciscaucasia. At least part of the raw material must have been imported from the south. The Maikop culture (connected with the Near East by vessels and figurines made of precious metal) used a bronze which is an alloy of copper, arsenic and nickel. This material, which does not seem to come from ores in Soviet territory, may have been imported from Anatolia. At the beginning of the second millennium B.c., however, it was supplanted by alloys from Caucasian deposits.

The arsenic bronzes of Caucasian origin had an enormous market reaching to the Dnieper in the west and to the Volga basin in the east and northward to the $55^{\text {th }}$ parallel. ${ }^{2}$ Ready-made goods seem to have been exported. Only in areas which were distant from trade routes but close to copper deposits were copies of prevalent models made.

The market for the Caucasian copper arsenic alloys collapsed, however, in the later second and early first millennium B.c. under the pressure of imports from the northeast (the Urals) and the east (eastern Kazakhstan). In the Urals and especially in East Kazakhstan large quantities of copper were

arsenic are great. Many copper ores have naturally occurring arsenic, but tin very rarely occurs naturally with copper. In Anatolia, the Cyclades and Crete (Early Minoan I) tin and arsenic bronzes were used together from the third millennium onward. 
produced and the rich deposits of tin ore were exploited for the production of bronze after the middle of the second millennium в.c. Other mining districts sprang up in the Altai and in the mountains encircling the Minusinsk basin.

In the steppes to the west of the Dnieper, however, the so-called Cimmerian bronzes prevailed. They are characterized by a high cobalt content and their types are related to those evolved in the progressive focal area of Transylvania.

The self-supporting Bronze Age of the steppes, which had its peak between the tenth and eighth centuries B.c., did not lead to strict uniformity of types. Metal working then was already an occupation familiar to all, and it was generally known that bronzes could be recast in any form desired without any technical detriment.

3 The second part of the paper deals with the Minusinsk and Ordos bronzes, with relations with China on the one hand and
The extensive trade in tin during the Late Bronze Age was based on horse-drawn wagons and carts, and perhaps also on sledges. Indeed the horse, which was useful also for military transport, was altering the scene rather quickly. From the end of the eighth century B.c. bands of mounted warriors crossed the Caucasus and were engaged as mercenaries by the warring powers of the Near East. On their return they brought with them the secrets of iron smelting and forging, and most probably even the blacksmiths themselves. Such "displaced persons" may have been employed at the court of the Scythian kings, east of the lower Dnieper. The neighboring tribes, mostly tributaries, soon possessed weapons made of the new metal. Only the arrowheads were still cast from bronze. ${ }^{3}$

UNIVERSITY OF HEIDELBERG

with Iran on the other. The problem of relations with the Hallstatt bronzes is also considered. 
Europe copper was generally replaced by bronze only around 1700 B.C., and Fatianovo was, in many respects, a culture of the Central European type although it is located in Eastern Europe?.

During the fourth millennium, in the area to the south of the main range of the Caucasus, we know of implements made of relatively pure copper only in some assemblages of Azerbaijan. In the following period, during the third millennium, in a much larger area including both Transcaucasia and Ciscaucasia, we meet with bronzes containing no tin but a high percentage of arsenic.

At least part of the raw material was imported from the south.

The Maikop culture of the Kuban basin (not to be confused with Koban, a village and culture in the Central Caucasus) which evidently had connections with the Near East-attested by vessels and figurines made from precious metals - used a bronze which is, in fact, an alloy of copper, arsenic and nickel, with up to $4.4 \%$ of nickel. This material does not seem to have come from ores in Soviet territory; perhaps it was imported from Anatolia. At the beginning of the second millennium, however, it was supplanted by alloys which can be explained as coming from Causasian deposits proper.

The arsenic bronze of Caucasian origin had an enormous market reaching to the Dnieper in the west and to the Volga basin in the east, and northwards to the 55 th parallel of latitude. Sporadic exports even occur in the Fatianovo culture. This diffusion is all the more astonishing as no trade of ingots has been observed. The tribes of the steppes and forest-steppes (i.e. the Pitand Timber-Grave cultures and the Poltavka culture) seem to have received ready-made goods, so there are no local variations. In areas far away from the trade routes but with copper deposits nearby, copies of the prevalent models were made.

The appearance of new metallurgical centers beyond the northeastern and eastern borders of this sphere of Caucasian influence and commerce created a new situation.

In the northeast, in the Urals, even the indigenous hunting and fishing tribes became active in mining, smelting, and casting. But the main impact came from the East. In Eastern Kazakhstan the Andronovo culture produced copper in large quantities. East Kazakhstan, moreover, has tich deposits of tin ore. Prehistoric mines of gigantic size have been discovered, and in one case more then a million tons of rock and ore had been removed. Owing to these circumstances the next step was soon taken and copper and tin were combined to produce what we normally call bronze.

Under the pressure of the imports from the north-east and east the market for the Caucasian copper-arsenic alloys collapsed. A further contributing factor was a migration of Eastern (Andronovo) tribes towards the west, into the basins of the Volga and Don during the later half of the second millennium B.C.

In the steppes to the west of the Dnieper, however, the so-called "Cimmerian bronzes" dominated, easily to be distinguished by their high cobalt content. The deposits of this alloy evidently lie outside the Soviet Union. The types are similar to those evolved in the progressive focal area of Transylvania.

In the meantime tin bronzes became prevalent even in large areas of the Caucasus. Tin is said to have come from the south together with new technical impulses.

The self-supporting Bronze Age of the steppes, which had its peak between the tenth and 7 B.G.Tikhonov, "Metallicheskie izdeliia epokhi bronzy na Srednem Urale i Priurale," MIA 90 (I960), pp.5-II 5. 
the eighth centuries B.C., did not lead to a strict uniformity of types. Metal working then was already an occupation familiar to all, and it was generally known that bronzes could be re-cast in any form desired, without any technical detriment.

The extensive trading in tin during the late Bronze Age was based on horse-drawn wagons and carts, and perhaps sledges too. Indeed, the horse, which was useful also for military transport, was altering the scene rather quickly. From the end of the eighth century B.C., bands of mounted warriors crossed the Caucasus and were engaged as mercenaries by the warring powers of the Near East. On their return they brought the secrets of iron melting and forging with them, and most probably even the blacksmiths themselves. Such "displaced persons" may have been employed at the court of the Scythian kings, east of the lower Dnieper. The neighbouring tribes, mostly tributaries, soon possessed weapons made of the new metal. Only the arrowheads were still cast from bronze.

Let us now definitely shift to Central Asia. So far we have only mentioned one aspect, namely the existence of a copper and tin producing focus in Eastern Kazakhstan. The bulk of the finds, however, come from what we call Southern Siberia, i.e. the Minusinsk basin, the Altai, and the Tuva. Towards the end of the third millennium B.C. we can distinguish a metallurgical tradition there using not alloys, but copper, though with many impurities. It seems that this practise was brought by immigrants. The appearance of such specialists in those remote regions must be explained by a process which took place in more southern regions-in Turkmenia, Tadzhikistan, Uzbekistan and Kirghizia. In recent years a considerable number of hoards has been found in these areas, containing moulds, unfinished tools, and raw materials, showing the rise of metallurgy in Central Asia ${ }^{8}$.

Soviet archaeologists think that the types represented in the hoards and in the few stratified sites (e. g. Zaman Baba) mostly depend on the cultures of the Iranian plateau (Plate I). The copper used came from local mines, but it could not be alloyed before the middle of the second millennium B.C. as the rich deposits of tin in Eastern Kazakhstan were still unknown.

There are a few exceptions - objects made from excellent bronze containing a large component of tin-but they are most certainly imports. In this connection the hoard of Khak in

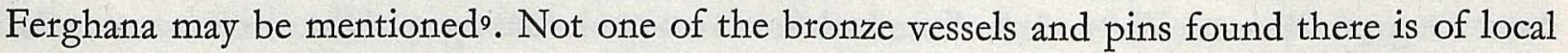
origin. The top of one pin (or wand) is decorated with figures featuring a man milking a cow. There are clear parallels with similar objects excavated at Tepe Hissar (III C), (cf.Plate II/I).

The tin-bronze export industries of Eastern Kazakhstan seem to have derived from the same source. They, in turn, seem to have influenced the Seima complex in North-Eastern Europe, and not vice versa.

The Minusinsk basin, which has ample resources of copper but is separated from the rest of Central Asia by difficult mountains, had an independent development. During the Karasuk period alloys of copper and arsenic were prevalent, as in Caucasia. Step by step the arsenic was replaced by tin, many bronzes containing both.9a

8 E.E. Kuzmina, Metallicheskie izdeliia eneolita i bronzovogo veka v srednei Azii (Arkheologiia SSSR B4-9) Moscow, I966, pp. 86-98.

9 I.V. Bogdanova-Berezovskaia, "Khimicheskii sostav metallicheskich izdelii Fergany epokhi bronzy i zheleza," MIA II 8 (1962), p.219.

9a D.V. Naumov, Proizvodstvo i obrabotka drevnikh mednykh i bronzovykh izdelii Minusinskoi kotloviny. "Novye metody $\mathrm{v}$ arkheologicheskikh issledovaniiakh", pp. I59-191. Moscow-Leningrad 1963. 


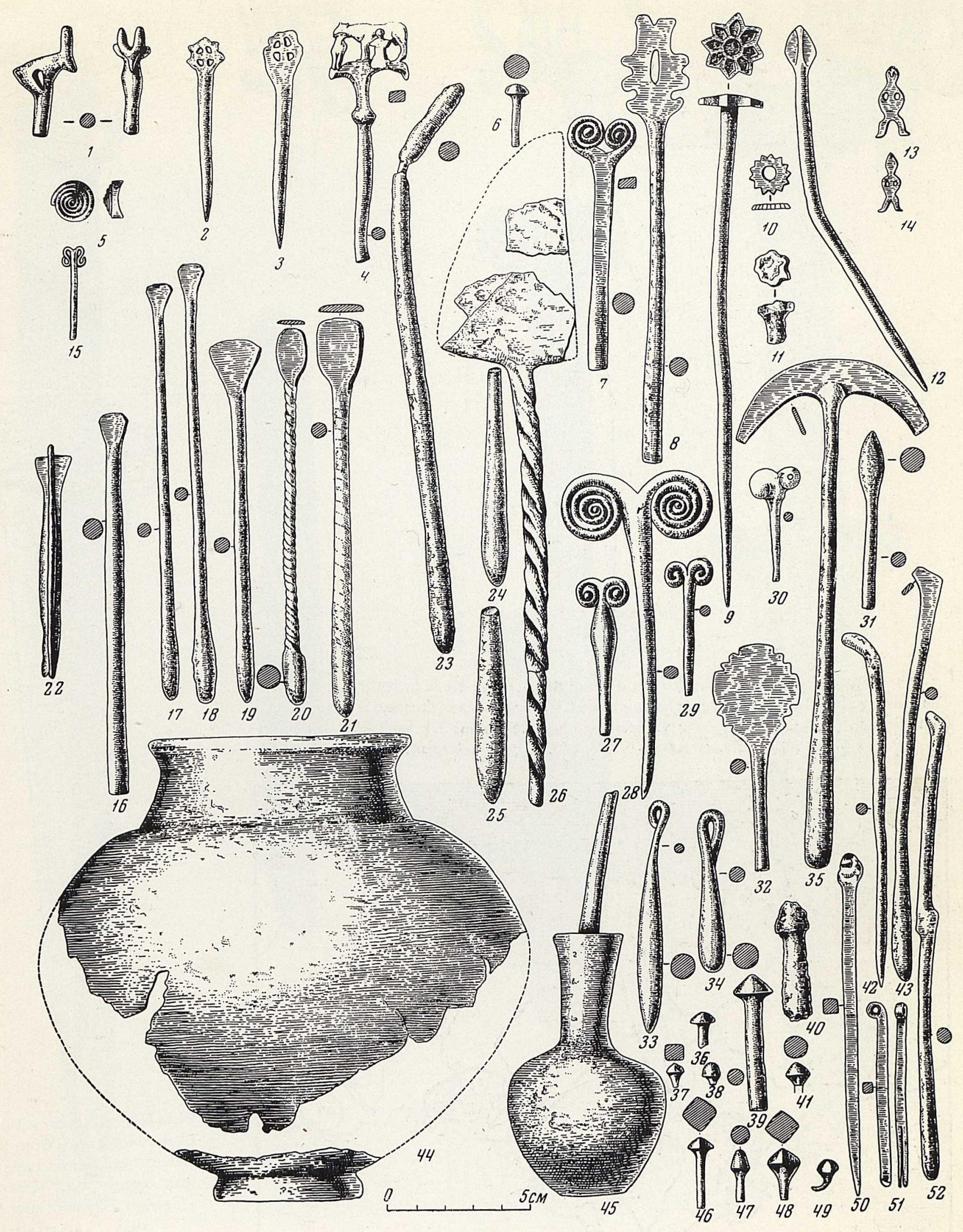

Plate I Pins and metal vessels found in Soviet Middle Asia I, I9, 3I, 32, 35, 39, 43, 45 - Altyn-depe; 2, 3-Iangi-kala; Plate I Pins and 4, 7, 80 - Takhirbai 3; I3, I4 - Aflatun; I6-18, 23, 37, 38 - Kara-depe; 20-22, 24, 25 - Zaman-baba; 6, 26 - Mulali-depe; 27-Shor-depe; 28 - Kizyl-Arvat; 33, 42, 52 - Til'kin-depe; 34 - Monzhukly-depe; 4I, 49-Geoksiur I. After Kuz'mina I 966, Pl. XVI. 

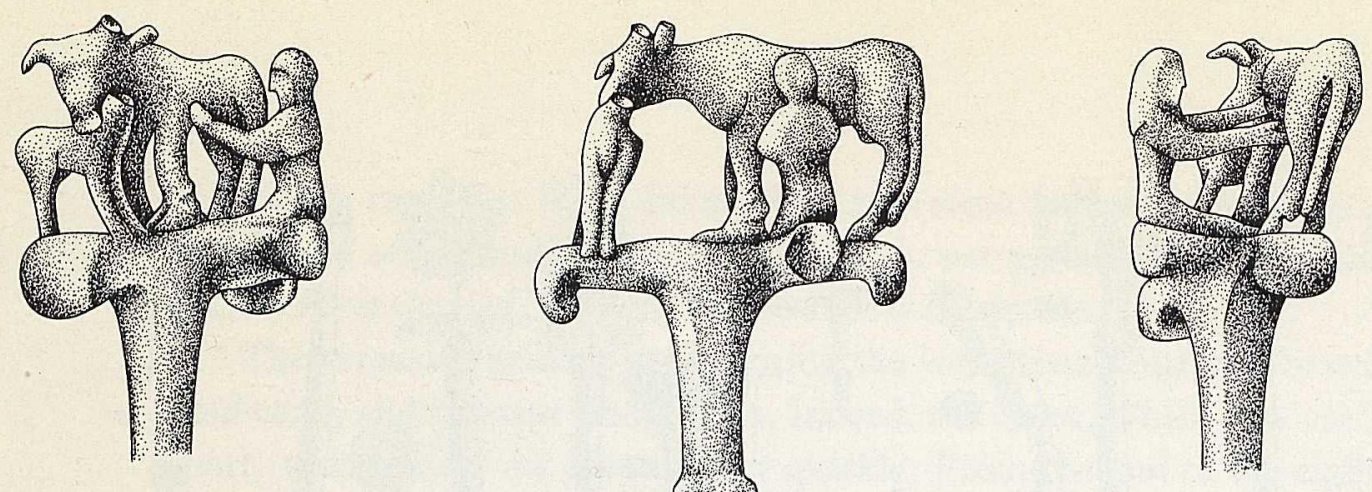

Plate II/ I Head of a pin (or wand) from the hoard of Khak in Ferghana.

The milking procedure with the cow licking the calf (or a calf-shaped dummy) is typical in early domestication (Drawing by Hedwig v.Eickstedt after S. Sorokin: Khakskii klad, in: Soobshcheniia Gos. Ermitazba XIX, I960. Slightly enlarged).

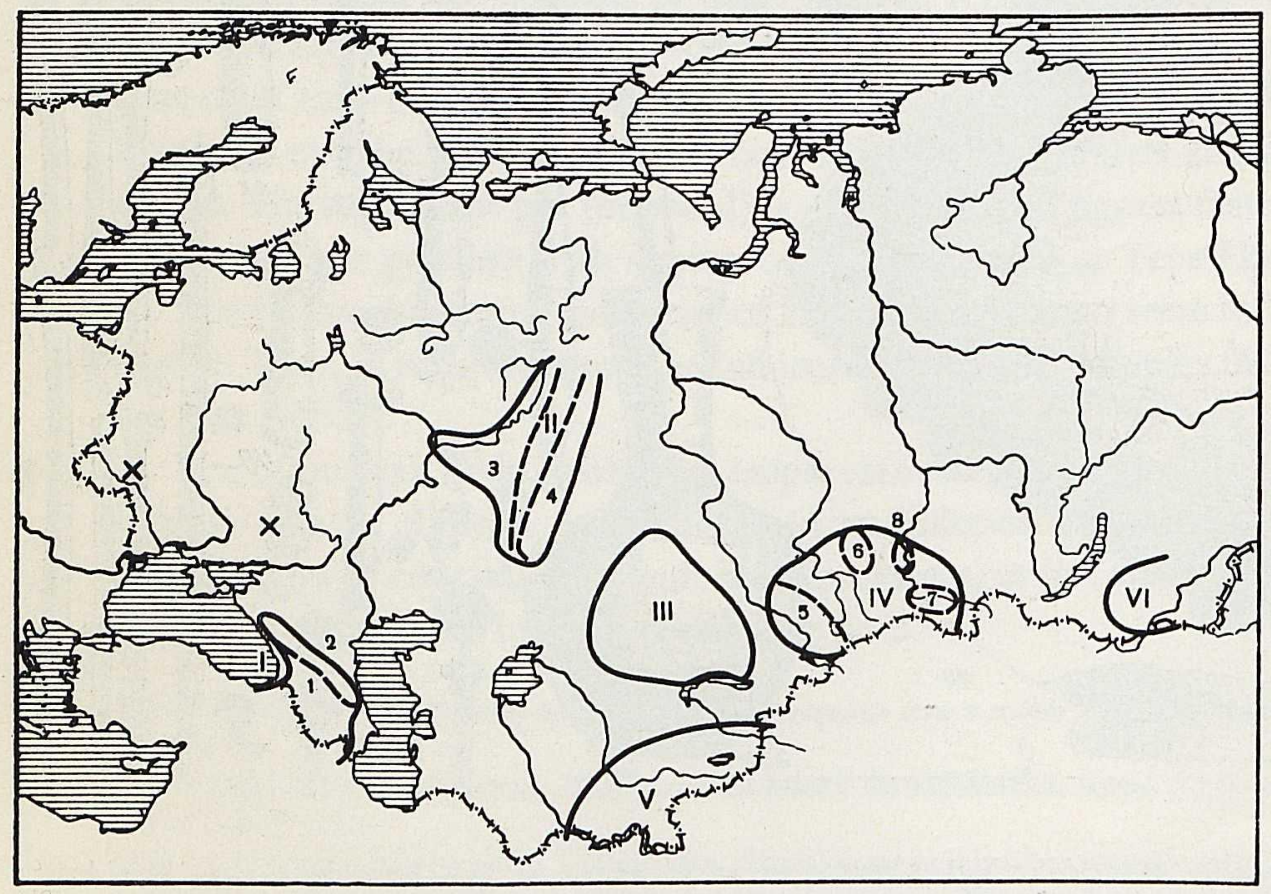

Plate II/3 Sketch-map of the metal-producing areas and traceable centers of early metallurgy in the territory of the U.S.S.R. Areas: I - Caucasus, II - Urals and Cis-Uralia, III - Kazakhstan, IV - Sayans-Altai, V - Middle Asia, VI - Trans-Baikalia Centers: I - Trans-Caucasia, 2 - North Caucasus, 3 - Cis-Uralia and the Volga region, 4-Urals, 5-Altaic mining districts, 6 - uplands of Shoria, 7 - Tuva, 8 - Minusinsk basin

$x$ - copper ores on the Donets and the Dniestr. After Chernykh I967 


$$
\text { lith }
$$



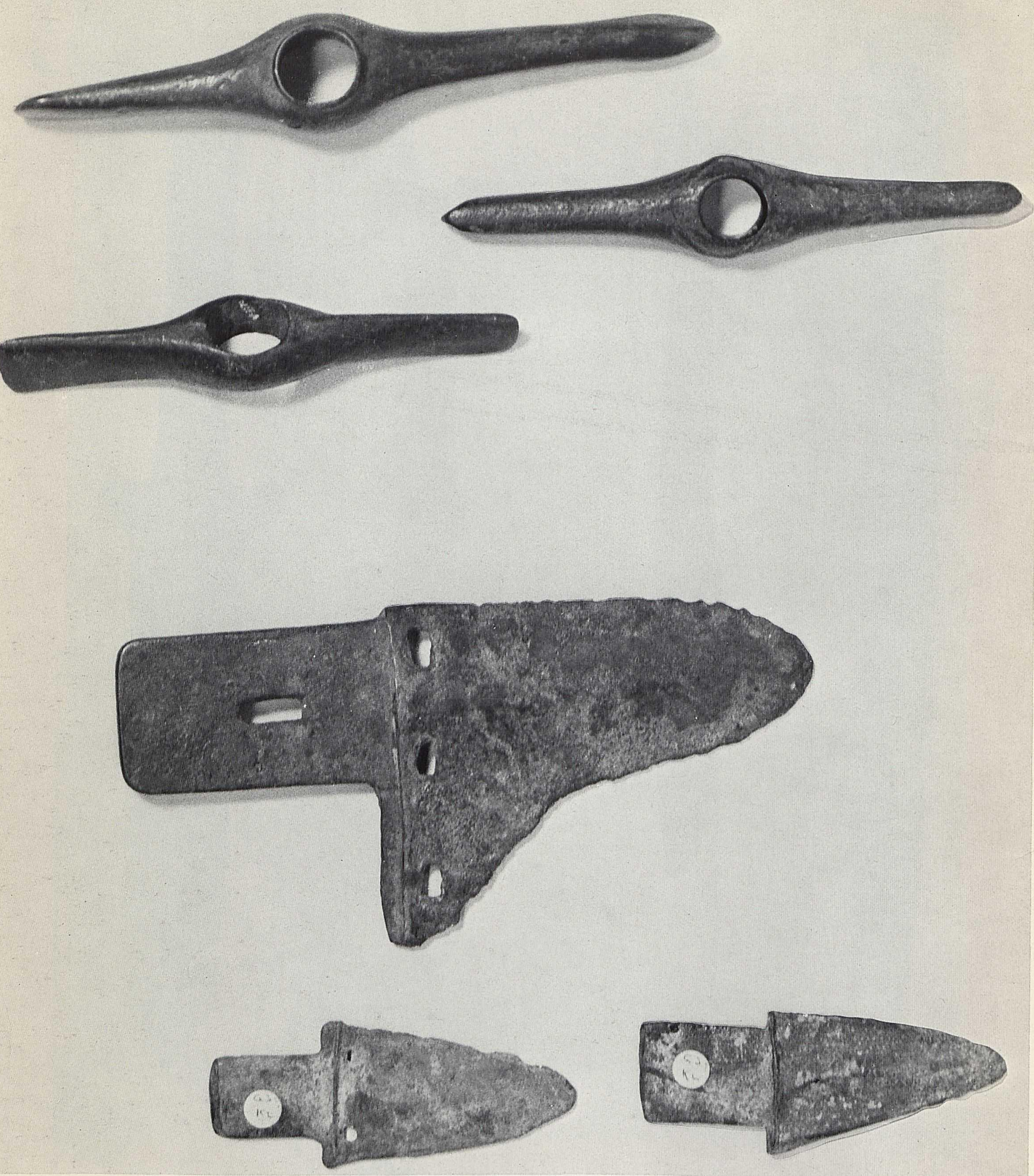

Plate IV Miniature picks and dagger axes $\left(K_{0}\right)$ compared to implements of normal size (Ordos bronzes in the Sackler Collection).

Miniatures of this kind may be explained as belonging to children's graves, as observed several times in the Minusinsk basin. 
The coming of iron in Central Asia was slow and late-as already attested by Herodotus, a contemporary of this development. In the Pontic area the period of transition was at the beginning of the sixth century B.C., but in the Altai and in Tuva it was at the end of the sixth and at the beginning of the fifth centuries. In Minusinsk, however, still farther away from the centers from which knowledge of the new metal came, the fully developed Iron Age started not earlier then the third and second centuries.

In Trans-Baikalia we find a similar limit, namely the third century B.C.

The Soviet archaeologists give a simple and plausible explanation for this. In the Sayans and in the Alatau there is an abundance of good copper ores, experienced pit-workers and smelters were at hand, and so there was no need for a substitute.

If we are willing to go beyond the horizon of our Soviet colleagues, we find another fascinating explanation. In China the metallurgy of copper alloys (with tin and lead as major components) had reached such a high standard that iron did not replace the bronze. In the sixth century B.C. it came in as an additional material and was manufactured in the same way as cast bronze (with a high content of carbon). This brittle substance, however, was not suitable for the production of cutting weapons, so it was reserved for agricultural implements and vessels. Weapons were now, as ever, made from the shining bronze. There is a theory that the terrible State of Ch'in was the first to use wrought-iron work for the mass production of iron swords, thanks to stimuli received from the West. This became a decisive factor in Ch'in's career of empirebuilding and slaughtering of all competitors ${ }^{10}$.

It seems that in Minusinsk too iron was known long before the full Iron Age. As in China, however, it was used as cast-iron and therefore did not replace bronze.

The decisive arguments in favour of this explanation are daggers which belong typologically to the beginning of the fifth century B.C., and which have a bronze blade and an iron hilt ${ }^{\mathrm{II}}$. They have nothing to do with the bronze-iron daggers of the Thraco-Cimmerian period which still have a bronze hilt, but have blades made from the sharp and dangerous iron (Plate II/2). Here the situation is reversed; Merhart observed the paradox but without understanding the reason ${ }^{12}$.

I believe the reason is that the makers of such weapons only knew cast, but not wrought iron. The rich decoration of the hilt of this type of dagger, in fact, and its perfect state of preservation, can only be explained by the process of casting.

This in turn, means that the full Iron Age came so late in the Minusinsk basin and in TransBaikalia because these areas belonged to the sphere of influence of Chinese metallurgy. In a surprisingly short period China had become one of the great centers of metallurgy, already using coal instead of charcoal, and producing iron implements on an almost industrial scale.

The influence of the technical achievements of Chinese craftsmen spread far and wide.

The famous bronze cauldrons of Southern Siberia were cast in rather crude sectional moulds which are, however, not different technically from the clay sectional moulds used for the making of the famous ritual bronze vessels of the Shang period. A little later the same technique was

\footnotetext{
ro Noel Barnard, Bronze Casting and Bronze Alloys in Ancient China (Monumenta Serica, Monograph XIV) Tokyo, I96I, pp. $\mathrm{I}_{3-23}$.

II M.A.Devlet, "Iz istorii osvoeniia metallurgii zheleza na Srednem Enisee," Sovetskaia Arkheologiia (1968/I), p. 30.

I2 Gero v. Merhart, Bronzezeit am Jenissei (Bücher zur Ur- und Frühgeschichte, r. Bd.), Wien, I926, pp. 165-166.
} 
adopted by the tribes of the Pontic area which had formerly used "Cimmerian" cauldrons made of thin sheets of copper connected by riveting ${ }^{13}$.

Scholars of the previous generation hat the idea that many Western types of Hallstatt origin were brought to China by a migration of warrior bands through the steppes towards the East, called the "Pontic Migration" by Heine-Geldern ${ }^{14}$. Nowadays it seems that many of these types of alleged Hallstatt origin, e.g. the "cruciform tubes" for the fixing of strap-crossings, were in fact already shaped by craftsmen of the Shang period, and were brought to the West by a mighty wave of Far Eastern influencers.

This is a rather crude outline of what we know about the history of metallurgy in Central Asia, and its most important connections with the West and the East. Most fascinating, perhaps, are the connections between the early centers of Asia and Iran. The treasure of Khak may mean that metallurgy extended eastwards from Northern Iran, finally influencing the Neolithic cultures of China. This was, in fact, proposed by Heine-Geldern many years ago ${ }^{\mathrm{I}}$.

In order to decide this question we need more and better series of analyses from the copper and bronze artifacts found in Northern Iran. The results must be fitted into the framework evolved by the Soviet authors. (cf. Plate II/3)

In the meantime we must restrict ourselves to typological considerations, but in this respect also something can be achieved. Some years ago a volume appeared listing all bronze and copper objects found in Western Turkestan ${ }^{17}$, that is the areas directly bordering on Iran and extending towards the northeast along the routes leading to Southern Siberia and China. Much of this material is related to different chronological groups on the plateau. It shows, at any rate, that the hoard of Khak is not an exception. In 1968 , on exhibition in Teheran, there were a mirror and an adze-axe from clandestine excavations in Northern Iran which were definitely related to our material. Chisels found in Turkestan belong to a type also represented in the graves of Sialk B.

On the other hand, some of the knives published by Kuzmina seem to have connections with Karasuk. Others are perhaps related to the earliest knives in China.

Many of the affinities which we can observe between Iran and the north were due to mounted warfare. Riders coming from the steppes and Central Asia ventured southwards and served as mercenaries in the armies of the great powers, for example Assyria. They returned, taking technical improvements with them. Such connections are reflected, to some extent, by the horse bridles in both areas, consisting of a bit and two cheek-pieces. These cheek-pieces are rods pierced by three openings. Some have been found in the East Aral basin, at Tagisken ${ }^{18}$, and have been dated from the eighth to the fifth centuries. "Cimmerian" examples from the East European Steppes date to the eighth and seventh centuries, and have mushroom-terminals similar to those on examples from Iran.

Modelled stones with prominent ram's horns on them are found in the forests east of the

I3 A. A. Jessen, "Nekotorye pamiatniki VIII-VII vv. do n.e. na Severnom Kavkaze," Voprosy skifo-sarmatskoi arkheologii (Moscow, 1954), P.I26.

14 R. von Heine-Geldern, "Das Tocharerproblem und die Pontische Wanderung," Saeculum II (I95 I), pp. $225-255$.

I5 M.v.Dewall, Pferd und Wagen im früben China (Saarbrücker Beiträge zur Altertumskunde I) I964, p. I I 2.

${ }^{16}$ R.von Heine-Geldern, "China, die ostkaspische Kultur und die Herkunft der Schrift," Paideuma IV (I950), pp.5 I-92.

17 Cf. Kuzmina, op.cit. in note 8.

I8 S.P.Tolstov and M.A.Itina, "Saki nizovev Syr-Dari," Sovetskaia Arkbeologiia (1966/2), p. 16r. 
Urals. Wild sheep are also shown on a knife from the same area. However, there are no wild sheep in this part of the Soviet Union. Recently similar stones have appeared in Iran, strengthening the connection and stressing the fact that the Urals culture is not a local development ${ }^{19}$.

I think that this is enough to confirm that the metallurgical affinities between Iran and Central Asia are matched by connections on the level of typology.

In the past Soviet authors have greatly stressed the connections between Eastern Europe and Central Asia because of their familiarity with both areas. Today a different tendency prevails: Chlenova claims that Karasuk is derived from Luristan ${ }^{20}$, and that the metallurgists of the Okunev culture came from the same direction in the early second millennium. If we carry this idea further, we must also include China in this picture of diffusions.

There is a second problem which should be mentioned here: the different composition of the bronzes of Minusinsk and those of China. I have stated that the Minusinsk basin belonged to the sphere of influence of Chinese metallurgy, and that the population of that area used cast iron from the beginning. There is a basic difference, however. The Chinese used copper alloys with a high content of lead, and the bronzes of the Tagar culture in the Minusinsk basin do not contain lead at all, but only copper, tin, and arsenic, besides the trace-elements.

In considering the Ordos bronzes in this respect, it must be remembered that this is only a convenient term applied to stray finds from several areas, most of them in Mongolia. The first analyses published by Samolin and Drew ${ }^{21}$ gave no clear answer but produced a rather chaotic picture: one Ordos bronze would contain a high proportion of lead, the next almost no lead, while some even contained zinc etc.

I think that I can now explain this: most of the animal plaques belong to a late stratum in Mongolian metallurgy, and can be ascribed to the Eastern Iron Age, the period when bronze weapons and tools were already obsolete and were being re-cast to produce ornaments. It seems that many of them were attached to clothing. In the Minusinsk basin, however, this kind of decoration was not popular, and this group, therefore, has no counterparts there. In some parts of Mongolia the animal style, restricted to such small ornaments, survived for a long time and finally influenced the art of the migration period.

In the meantime the Sackler laboratory began to analyse "Ordos" daggers and knives, that is, objects which really do belong to the Bronze Age, and here the picture seems to be much clearer. Most of the objects contain not only tin, but also lead; they therefore belong to the Far Eastern group and not to the Central Asian.

This is in accordance with another result of my investigations, namely, that the affinities between Ordos and Minusinsk are not so strong as I had hoped, and that furthermore the so-called Karasuk types apparently survived for a whole millennium.

I believe that when all the material has been tested-there are more than I,300 piecesseveral groups will be discernible indicating different focal centers in Mongolia (such a group would be tepresented by the "spoon-knives" which are mostly made from copper containing a considerable amount of arsenic).

19 Karl Jettmar, "The Slab with a Ram's head in the Rietberg Museum," Artibus Asiae XXVII/4 (1964/65), pp. $291-300$.

20 N. L.Chlenova, "Karasukskaia kultura v Iuzhnoi Sibiri," Istoriia Sibiri vol. I (Materialy po drevnej istorii Sibiri) UlanUde, 1964 .

${ }^{2 I}$ W. Samolin and I.M.Drew, "Eurasian Animal Style Plaques I," Monumenta Serica vol. XXIV (I965), pp. I-I4. 


\section{Contributions after the lecture beld at Columbia University}

At the conclusion of his presentation the author, aided by Isabella Drew, showed some of the Ordos bronzes from the Sackler Collection, and stressed the fact that many were miniatures of actual implements (Plate III and IV). In the Minusinsk basin the use of miniatures in graves began in the fifth or fourth centuries B.C. The use of miniatures in the sanctuaries of Luristan was mentioned, as were examples dating to the reign of the Assyrian King Shalmaneser III ( 858 to 824 B.C.).

Daggers were shown which all had a high lead content (one exception was a tin-bronze). These have Sarmatian parallels and Chinese excavations have produced some dating to the Early Warring States of the fifth century B.C. Most of them are made by piece-mould casting, a Chinese speciality used with lead alloys. In the Minusinsk basin where tin alloys are prevalent, lead bronzes are used exceptionally to make moulds since this produces sharper outlines. It is because of this use of lead alloys that Chinese bronzes are so fine.

In the subsequent discussion several important points were made. The replacement of arsenic bronzes by tin bronzes was due not to the fact that the latter are better, for the arsenic alloy is at least as good as the tin alloy, but most probably because of the great dangers to the workers' health involved in using arsenic.

Many copper ores have naturally occurring arsenic but tin very rarely occurs naturally with copper. In Anatolia, the Cyclades and Crete (Early Minoan I) tin and arsenic bronzes were used together from the third millennium onwards.

R.H.Dyson, Jr. stated that all the metal objects from Tepe Hissar in the University Museum, Philadelphia, had been analyzed and almost all were of natural copper. The specimen from the Khak treasure which is paralleled at Hissar was, however, made from a very fine tin-bronze. Geoy Tepe material from level K contemporary with Hissar II-A to III-B showed that an arsenic-copper alloy was used there.

Impurities in a bronze can be analysed to identify the mine, but often mines have been worked for so long that new strata have been reached which contain different impurities.

The exchange of ideas between East and West during the Hallstatt period was mentioned, together with the part played by the Cimmerians in it. The exchange was not one-sided, however, and the Chinese, who had previously used square cheek-pieces, went over to cheek-pieces in the shape of the prong of an antler which have European prototypes ${ }^{22}$. Points of contact between East and West are likely to be best represented by horse accoutrement. Pottery is not a good criterion since that of the Minusinsk basin is related to the pottery of the whole of the Northern Steppes and the forests, with only local variations.

The question of ingots was brought up. It was pointed out that in different areas metals were transported in the shape of objects. "Arrow-heads" seem to have been used as currency (as mentioned by Herodotus) and some have been found which could never have been used as anything else since no provision has been made for their hafting. ${ }^{23}$

22 Karl Jettmar, Review of M.v. Dewall, Pferd und Wagen im früben China in Central Asiatic Journal XI/4 (1966) pp. 3 I I-3I6.

${ }_{23}$ B.N. Grakov, Legenda o skifskom tsare Ariante (Gerodot, kn. IV, gl. 8I). "Istoriia, arkheologiia i etnografiia Srednei Azii", pp. IOI-II s. Moscow I 968. 